\title{
Clinical Hypertension
}

\section{Hypertension, renin-angiotensin- aldosterone-system-blocking agents, and COVID-19}

Si-Hyuck Kang ${ }^{1,2,3} \mathbb{D}$, Dong-Hoon Lee $\mathbb{B}^{1}$, Kyung-Do Han ${ }^{4} \mathbb{D}$, Jin-Hyung Jung ${ }^{5} \mathbb{D}$, Sang-Hyun Park ${ }^{5} \mathbb{D}$, Andrew M. Dai ${ }^{3} \mathbb{D}$, Henry G. Wei ${ }^{3} \mathbb{D}$, Chang-Hwan Yoon ${ }^{1,2}$, Tae-Jin Youn ${ }^{1,2} \mathbb{D}$, In-Ho Chae ${ }^{1,2^{*}}$ and Cheol-Ho Kim ${ }^{1,2}$

\begin{abstract}
Background: There have been concerns regarding the safety of renin-angiotensin-aldosterone-system (RAAS)blocking agents including angiotensin-converting enzyme inhibitors (ACEI) and angiotensin receptor blockers (ARB) during the coronavirus disease 2019 (COVID-19) pandemic. This study sought to evaluate the impact of hypertension and the use of ACEI/ARB on clinical severity in patients with COVID-19.

Methods: A total of 3,788 patients aged 30 years or older who were confirmed with COVID-19 with real time reverse transcription polymerase chain reaction were identified from a claims-based cohort in Korea. The primary study outcome was severe clinical events, a composite of intensive care unit admission, need for ventilator care, and death.

Results: Patients with hypertension ( $n=1,190,31.4 \%)$ were older and had higher prevalence of comorbidities than those without hypertension. The risk of the primary study outcome was significantly higher in the hypertension group, even after multivariable adjustment (adjusted odds ratio [aOR], 1.67; $95 \%$ confidence interval [Cl], 1.04 to 2.69). Among 1,044 patients with hypertensive medical treatment, 782 (74.9\%) were on ACEI or ARB. The ACEI/ARB subgroup had a lower risk of severe clinical outcomes compared to the no ACEI/ARB group, but this did not remain significant after multivariable adjustment ( $a \mathrm{OR}, 0.68 ; 95 \% \mathrm{Cl}, 0.41$ to 1.15$)$.

Conclusions: Patients with hypertension had worse COVID-19 outcomes than those without hypertension, while the use of RAAS-blocking agents was not associated with increased risk of any adverse study outcomes. The use of ACE inhibitors or ARBs did not increase the risk of adverse COVID-19 outcomes, supporting current guidance to continue these medications when indicated.
\end{abstract}

Keywords: Coronavirus infections, Hypertension, Angiotensin-converting enzyme inhibitors, Angiotensin receptor antagonists

\footnotetext{
* Correspondence: ihchae@snu.ac.kr

${ }^{1}$ Cardiovascular Center, Department of Internal Medicine, Seoul National University Bundang Hospital, Seongnam, Republic of Korea

${ }^{2}$ Department of Internal Medicine, Seoul National University College of Medicine, Seoul, Republic of Korea

Full list of author information is available at the end of the article
}

(c) The Author(s). 2021 Open Access This article is licensed under a Creative Commons Attribution 4.0 International License, which permits use, sharing, adaptation, distribution and reproduction in any medium or format, as long as you give appropriate credit to the original author(s) and the source, provide a link to the Creative Commons licence, and indicate if changes were made. The images or other third party material in this article are included in the article's Creative Commons licence, unless indicated otherwise in a credit line to the material. If material is not included in the article's Creative Commons licence and your intended use is not permitted by statutory regulation or exceeds the permitted use, you will need to obtain permission directly from the copyright holder. To view a copy of this licence, visit http://creativecommons.org/licenses/by/4.0/ The Creative Commons Public Domain Dedication waiver (http://creativecommons.org/publicdomain/zero/1.0/) applies to the data made available in this article, unless otherwise stated in a credit line to the data. 


\section{Background}

The coronavirus disease 2019 (COVID-19) is a global pandemic causing millions of deaths worldwide as of March $2021[1,2]$. The pathogen of the disease, severe acute respiratory syndrome coronavirus-2, uses a densely glycosylated spike (S) protein to gain entry into host cells [3]. Studies have suggested that the host receptor angiotensinconverting enzyme 2 (ACE2) is the target of the $S$ protein receptor-binding domain, and that the interaction regulates the transmission of the disease $[4,5]$.

Amid the COVID-19 pandemic, concerns have been raised that the use of renin-angiotensin-aldosterone-system (RAAS)-blocking agents, such as ACE inhibitors (ACEI) and angiotensin receptor blockers (ARB) may increase the susceptibility to or aggravate the severity of COVID-19. There have been studies suggesting blockade of either angiotensin II synthesis or activity increases the gene expression and activity of ACE2 [6, 7]. Observations that patients with hypertension are associated with worse clinical outcomes triggered the concerns that the use of ACEI or ARB may be linked with their poor prognosis.

Major cardiology societies pointed out that such speculations lack sound clinical evidence, and strongly recommended that physicians and patients should continue treatment with their usual antihypertensive therapy [8, 9]. Hypertension is one of the most common diseases, and strong evidence supports the benefit of medical treatment for hypertension [10-12]. ACEI and ARB are among the most widely used antihypertensive medications. In contrary to the initial concerns, multiple studies have proven their safety in terms of COVID-19 susceptibility and severity $[13,14]$. This study aimed at estimating the impact of hypertension and the use of ACEI/ $\mathrm{ARB}$ on severe clinical outcomes among Korean patients confirmed with COVID-19.

\section{Methods}

\section{Data source and patients}

South Korea is one of the countries severely affected by COVID-19: more than 20,000 patients have been diagnosed and approximately 380 died as of September 2020. In response to scientific needs, the government of Korea allowed access to de-identified COVID-19 nationwide patient data based on the Korean National Health Insurance System [15]. The insurance system covers more than $97 \%$ of residents in Korea. The cohort comprised 5,483 patients confirmed by real time reverse transcription polymerase chain reaction (RT-PCR) until April 4, 2020. Hospitalized patients as well as those treated at outpatient clinics were included. The database consisted of claims information during the COVID-19 illness and the previous 5 years. Adults aged 30 years or older $(n=3,788)$ were chosen in this study because hypertension is rare in younger populations [16]. This study was exempt from review by the Seoul National University Bundang Hospital Institutional Review Board (IRB No: X-2005-611-902). It complied with the requirements of the 2013 Declaration of Helsinki, and the need for informed consent was waived.

\section{Definitions}

A subject was considered to have hypertension if (a) hypertension was diagnosed once or more during a hospitalization, or at two or more outpatient clinic visits; or (b) a history of antihypertensive medication prescription for more than 1 month during the prior 1 year. Subjects with antihypertensive medical treatment were classified into an ACEI/ARB or non-ACEI/ARB group according to the prescription in the year prior: ACEI/ $\mathrm{ARB}$ use was necessary regardless of combined use of other antihypertension medications to suffice the ACEI/ ARB group, while non-ACEI/ARB group definition included any antihypertension drugs other than ACEI or ARB. Previous medical history, such as ischemic heart disease, stroke, congestive heart failure, chronic obstructive pulmonary disease, and cancer, was identified based on International Classification of Diseases-10 codes from the previous 5-year claim data [17]. The primary study outcome was a composite of intensive care unit (ICU) admission, need for ventilator care, and death. Secondary outcomes included hospitalization, oxygen requirement, ICU admission, need for ventilator care, and death related to COVID-19.

\section{Statistical analysis}

Summary statistics are reported as means \pm standard deviations for numerical variables and as numbers (percentages) for categorical variables. Continuous variables were compared using the Student t-test or the MannWhitney U-test, as appropriate. Categorical variables were compared using the chi-squared test. Logistic regression models were used to calculate odds ratios (ORs) and $95 \%$ confidence intervals (CIs). Multivariable regression models were constructed with adjustment for (a) age (continuous) and sex, and (b) including age, sex, diabetes mellitus, chronic kidney disease, chronic obstructive pulmonary disease, and cardiovascular disease. A two-sided $P<0.05$ was considered statistically significant. Statistical analyses were performed using SAS ver. 9.2 (SAS Institute, Cary, NC, USA).

\section{Results}

\section{Hypertension and COVID-19 outcomes}

Among 3,788 adults aged 30 years or older who were diagnosed with COVID-19, 1,190 (31.4\%) had hypertension (Fig. 1). As shown in Table 1, the two groups showed significantly different age distributions. While the number peaked at 30 to 39 years and decreased 


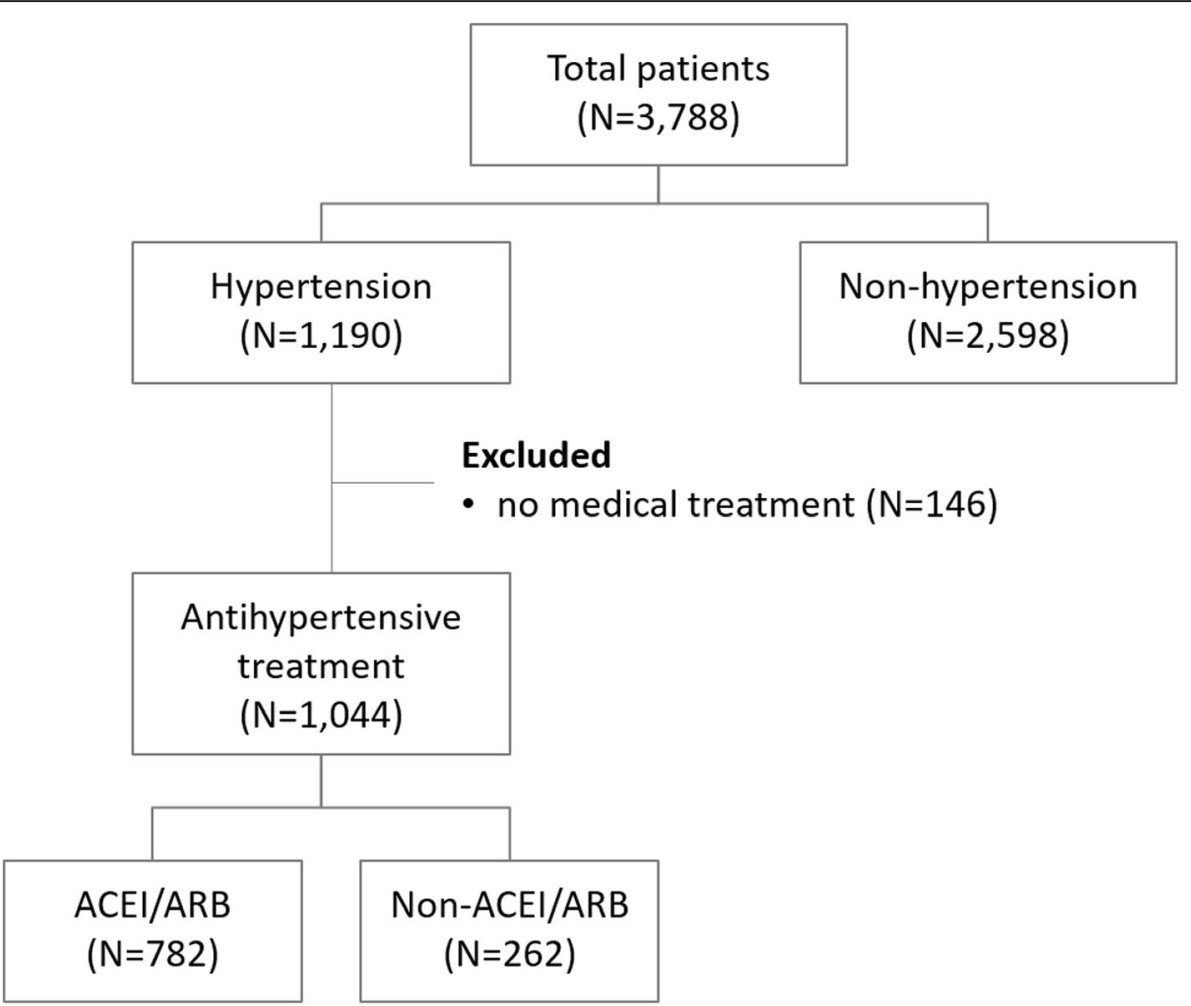

Fig. 1 Study flow diagram. ACEl, angiotensin-converting enzyme inhibitors; ARB, angiotensin receptor blockers

Table 1 Baseline characteristics of study population

\begin{tabular}{|c|c|c|c|c|}
\hline Characteristic & $\begin{array}{l}\text { Total } \\
(n=3,788)\end{array}$ & $\begin{array}{l}\text { Hypertension } \\
(n=1,190)\end{array}$ & $\begin{array}{l}\text { Non-hypertension } \\
(n=2,598)\end{array}$ & $P$-value \\
\hline Age (yr) & $52.1 \pm 15.1$ & $63.9 \pm 14.0$ & $46.7 \pm 12.3$ & $<0.001$ \\
\hline Age distribution (yr) & & & & $<0.001$ \\
\hline 3039 & $970(25.6)$ & $57(4.8)$ & $913(35.1)$ & \\
\hline $40 \quad 49$ & $860(22.7)$ & $142(11.9)$ & $718(27.6)$ & \\
\hline $50 \quad 59$ & $808(21.3)$ & $259(21.8)$ & $549(21.1)$ & \\
\hline 6069 & $570(15.0)$ & $289(24.3)$ & $281(10.8)$ & \\
\hline 7079 & $374(9.9)$ & $271(22.8)$ & $103(4.0)$ & \\
\hline 80-89 & $180(4.8)$ & $151(12.7)$ & $29(1.1)$ & \\
\hline$\geq 90$ & $26(0.7)$ & $21(1.8)$ & $5(0.2)$ & \\
\hline Male sex & $1,692(44.7)$ & $605(50.8)$ & $1,087(41.8)$ & $<0.001$ \\
\hline \multicolumn{5}{|l|}{ Comorbidity } \\
\hline Diabetes & $655(17.3)$ & $483(40.6)$ & $172(6.6)$ & $<0.001$ \\
\hline Dyslipidemia & $1,103(29.1)$ & $716(60.2)$ & $387(14.9)$ & $<0.001$ \\
\hline Chronic kidney disease & $234(6.2)$ & $213(18.0)$ & $21(0.8)$ & $<0.001$ \\
\hline Chronic obstructive pulmonary disease & $387(10.2)$ & $213(18.0)$ & $174(6.7)$ & $<0.001$ \\
\hline Cancer & $313(8.3)$ & $153(12.9)$ & $160(6.2)$ & $<0.001$ \\
\hline Cardiovascular disease & $513(13.5)$ & $429(36.1)$ & $84(3.2)$ & $<0.001$ \\
\hline Ischemic heart disease & $269(7.1)$ & $226(19.0)$ & $43(1.7)$ & $<0.001$ \\
\hline Myocardial infarction & $36(1.0)$ & $34(2.9)$ & $2(0.1)$ & $<0.001$ \\
\hline Stroke & $185(4.9)$ & $163(13.7)$ & $22(0.8)$ & $<0.001$ \\
\hline Congestive heart failure & $223(5.9)$ & $191(16.1)$ & $32(1.2)$ & $<0.001$ \\
\hline
\end{tabular}

Data are presented as mean \pm standard deviation or number (\%) 
linearly with an increasing age in the non-hypertension group, the hypertension group showed a broader peak between 50 and 79 years. The proportions of male sex, diabetes, chronic kidney disease, chronic obstructive pulmonary disease, cardiovascular disease, and cancer were also higher in the hypertension group.

The hypertension group showed significantly poor outcomes compared to the non-hypertension group (Table 2; Fig. 2). ORs for the primary study outcome, a composite of ICU admission, ventilator care, and death, were 5.18 ( $95 \% \mathrm{CI}, 3.51$ to 7.65 ) before adjustment and 1.67 (1.04 to 2.69) after multivariable adjustment. While hospitalization and oxygen requirement also occurred more frequently, they were not significant after adjustment.

\section{RAAS-blocking agents and COVID-19 outcomes}

Regarding antihypertensive medical treatment, 782 out of 1,044 hypertensive adults (74.9\%) were prescribed ACEI or ARB (Fig. 1). The ACEI/ARB group showed a younger age and higher frequencies of diabetes, dyslipidaemia, and chronic kidney disease, while the proportion of cancer was significantly lower than the non-ACEI/ ARB group (Table 3; Fig. 2). Meanwhile, the two groups showed disparate patterns in antihypertensive medical treatment.

Table 4 shows unadjusted and multivariable-adjusted risk estimates for the study outcomes. The primary endpoint occurred in a lower rate in the ACEI/ARB group before adjustment, which lost significance after adjustment (OR, 0.68 ; $95 \% \mathrm{CI}, 0.41$ to 1.15 ). While ICU admission and ventilator care tended to be lower in the ACEI/ARB group with marginal significance, no other study endpoints differed significantly.

\section{Discussion}

The present study showed patients with hypertension more frequently experienced adverse outcomes than those without hypertension when they have COVID-19 illness. The excess was greater with severe events such as ICU admission, ventilator care, and death, whereas it was less prominent with less severe events such as hospitalization and oxygen requirement. Another important finding of this study is that the use of RAAS-blocking agents such as ACEI and ARB was not associated with increased risk of poor clinical prognosis associated with COVID-19 illness.

The present study showed that use of RAAS-blocking agents does not adversely affect clinical outcomes during COVID-19 illness. Several recent studies consistently showed reassuring results regarding the safety of ACEI/ ARB during the pandemic. Two studies from China also analyzed hospitalized patients and found no excess in mortality associated with the use of ACEI/ARB $[18,19]$. Several studies even suggested lower risk of mortality associated with ACEI/ARB use $[19,20]$.

The current evidence of ACE2 upregulation after chronic exposure to ACEI and ARB is mostly focused on cardiovascular tissue [6,7]. There is still no evidence that they increase lung-specific ACE2 expression [13]. In addition, experimental animal models have shown mixed findings suggesting the complexity underlying RAAS responses to pathway modulators [13]. The present study provides clinical evidence supporting that patients who are taking ACEI or ARB should not discontinue their current treatment during the COVID-19 pandemic.

Previous studies have shown that hypertension is the most frequent comorbidity among patients with COVID-19 and that it is also frequent in those with adverse clinical outcomes $[2,21]$. This study also showed hypertension poses a risk factor for poor prognosis in patients with COVID-19. They were also significantly older and had higher prevalence of comorbidities. Although adjustment for such factors partially attenuated the risks, they remained significantly greater.

This study similarly showed hypertension was the most frequent comorbidity in this study population. However, the proportion (31.4\%) was numerically similar to the prevalence in the general Korean population $(30.5 \%$ in adults aged 30 years or older) $[16,22]$.

Table 2 Clinical outcomes according to the presence of hypertension

\begin{tabular}{|c|c|c|c|c|c|c|c|c|c|c|c|c|}
\hline \multirow{3}{*}{$\begin{array}{l}\text { Clinical } \\
\text { outcome }\end{array}$} & \multirow{3}{*}{$\begin{array}{l}\begin{array}{l}\text { Total } \\
(\boldsymbol{n}=\mathbf{3 , 7 8 8})\end{array} \\
1,481(39.1)\end{array}$} & \multirow{3}{*}{$\begin{array}{l}\text { Hypertension } \\
(n=1,190)\end{array}$} & \multirow{3}{*}{$\begin{array}{l}\text { Non- } \\
\text { hypertension } \\
(\boldsymbol{n}=\mathbf{2}, \mathbf{5 9 8}) \\
894(34.4)\end{array}$} & \multicolumn{3}{|c|}{ Unadjusted } & \multicolumn{3}{|c|}{ Age, sex-adjusted } & \multicolumn{3}{|c|}{ Multivariable adjusted } \\
\hline & & & & \multicolumn{2}{|c|}{ OR $(95 \% \mathrm{Cl})$} & \multirow{2}{*}{$\begin{array}{l}P \text {-value } \\
<0.001\end{array}$} & \multicolumn{2}{|c|}{ OR (95 \% Cl) } & \multirow{2}{*}{$\begin{array}{l}P \text {-value } \\
0.634\end{array}$} & \multicolumn{2}{|c|}{ OR $(95 \% \mathrm{Cl})$} & \multirow{2}{*}{$\frac{P \text {-value }}{0.146}$} \\
\hline & & & & $1.86(1.61$ & 2.13) & & $0.96(0.81$ & 1.14) & & $1.15(0.95$ & 1.38) & \\
\hline $\begin{array}{l}\text { Oxygen } \\
\text { requirement }\end{array}$ & $267(7.0)$ & $154(12.9)$ & $113(4.3)$ & $3.27(2.54$ & $4.21)$ & $<0.001$ & $1.24(0.92$ & 1.68) & 0.159 & $1.33(0.96$ & 1.83) & 0.083 \\
\hline Severe outcome & $123(3.2)$ & $85(7.1)$ & $38(1.5)$ & $5.18(3.51$ & 7.65) & $<0.001$ & $1.66(1.06$ & 2.59) & 0.026 & $1.67(1.04$ & 2.69) & 0.034 \\
\hline ICU admission & $55(1.5)$ & $38(3.2)$ & $17(0.7)$ & $5.01(2.82$ & $8.91)$ & $<0.001$ & $2.59(1.33$ & $5.05)$ & 0.005 & $2.69(1.33$ & $5.43)$ & 0.006 \\
\hline Ventilator care & $34(0.9)$ & $25(2.1)$ & $9(0.3)$ & $6.17(2.87$ & 13.3) & $<0.001$ & $2.50(1.05$ & 5.94) & 0.038 & $2.85(1.18$ & $6.92)$ & 0.020 \\
\hline Death & $83(2.2)$ & $61(5.1)$ & $22(0.8)$ & $6.32(3.87$ & 10.3) & $<0.001$ & $1.36(0.78$ & 2.36) & 0.274 & $1.24(0.69$ & $2.25)$ & 0.473 \\
\hline
\end{tabular}

Data are presented as number (\%) unless otherwise specified 


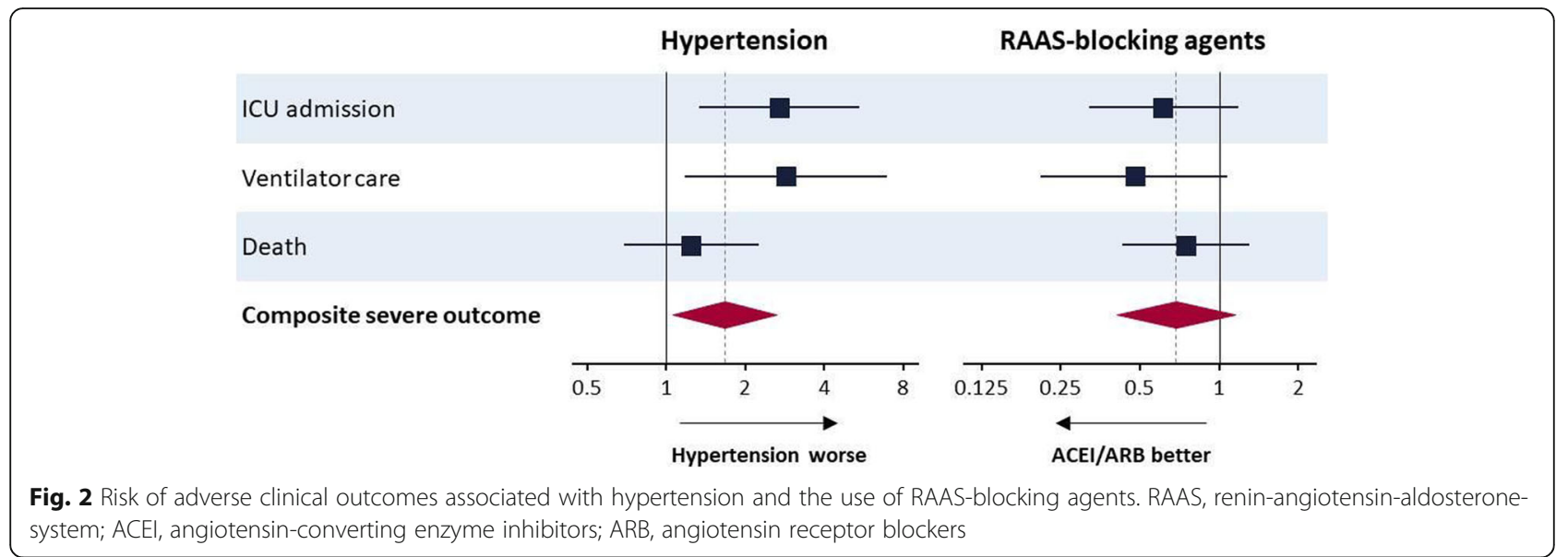

Regarding to the role of RAAS-blocking agents, Mancia et al. [14] recently performed a well-designed casecontrol study to demonstrate that ACEI or ARB did not affect the risk of COVID-19. Subsequent studies also confirmed the safety of ACEI and ARB in terms of likelihood of COVID-19 infection [23, 24].

One of the strengths of the present study is the broad spectrum of study population including outpatients as well as in-hospital patients. Vigorous contact-tracing and extensive testing were performed in Korea [25]. The low rate of mortality $(2.2 \%)$ in this study compared to other studies with RAAS-blocking agents $(5.8 \%, 8.8 \%$, and $11.0 \%)$ partly reflects the situation $[18,19]$. We believe it ensures low risk of selection bias in this study. However, this study also has limitations. Firstly, because the cohort consisted of a claims database, study variables were defined using operational definitions. However, the use of claims data also ensures the data integrity of

Table 3 Comparison of baseline characteristics of hypertensive adults according to antihypertensive treatment

\begin{tabular}{|c|c|c|c|c|}
\hline Characteristic & $\begin{array}{l}\text { Antihypertensive treatment } \\
(n=1,044)\end{array}$ & $\begin{array}{l}\text { ACEI/ARB } \\
(n=782)\end{array}$ & $\begin{array}{l}\text { Non-ACEI/ARB } \\
(n=262)\end{array}$ & $P$-value \\
\hline Age (yr) & $63.8 \pm 14.1$ & $63.0 \pm 14.2$ & $66.2 \pm 13.6$ & 0.002 \\
\hline Male sex & $525(50.3)$ & $401(51.3)$ & $124(47.3)$ & 0.268 \\
\hline \multicolumn{5}{|l|}{ Comorbidity } \\
\hline Diabetes & $410(39.3)$ & $333(42.6)$ & $77(29.4)$ & 0.002 \\
\hline Dyslipidemia & $620(59.4)$ & $481(61.5)$ & $139(53.1)$ & 0.016 \\
\hline Chronic kidney disease & $177(17.0)$ & $144(18.4)$ & $33(12.6)$ & 0.030 \\
\hline Chronic obstructive pulmonary disease & $181(17.3)$ & $134(17.1)$ & $47(17.9)$ & 0.766 \\
\hline Cancer & $119(11.4)$ & $80(10.2)$ & $39(14.9)$ & 0.040 \\
\hline Cardiovascular disease & $358(34.3)$ & $261(33.4)$ & $97(37.0)$ & 0.282 \\
\hline Ischemic heart disease & $185(17.7)$ & $137(17.5)$ & $48(18.3)$ & 0.769 \\
\hline Myocardial infarction & $27(2.6)$ & $23(2.9)$ & $4(1.5)$ & 0.212 \\
\hline Stroke & $137(13.1)$ & $97(12.4)$ & $40(15.3)$ & 0.235 \\
\hline Congestive heart failure & $163(15.6)$ & $113(14.5)$ & $50(19.1)$ & 0.074 \\
\hline \multicolumn{5}{|l|}{ Antihypertensive treatment } \\
\hline ACEI & $51(4.9)$ & $51(6.5)$ & 0 & $<0.001$ \\
\hline ARB & 744 (71.3) & $744(95.1)$ & 0 & $<0.001$ \\
\hline$\beta$-blockers & $183(17.5)$ & $122(15.6)$ & $61(23.3)$ & 0.005 \\
\hline Calcium channel blockers & $593(56.8)$ & $422(54.0)$ & $171(65.3)$ & 0.001 \\
\hline Diuretics & $223(21.4)$ & $187(23.9)$ & $36(13.7)$ & 0.001 \\
\hline Others & $100(9.6)$ & $48(6.1)$ & $52(19.8)$ & $<0.001$ \\
\hline
\end{tabular}

Data are presented as mean \pm standard deviation or number (\%) 
Table 4 Clinical outcomes according to the use of RAAS blockers

\begin{tabular}{|c|c|c|c|c|c|c|c|c|c|}
\hline \multirow{2}{*}{$\begin{array}{l}\text { Clinical } \\
\text { outcome }\end{array}$} & \multirow{2}{*}{$\begin{array}{l}\text { Antihypertensive } \\
\text { treatment } \\
(n=1,044)\end{array}$} & \multirow{2}{*}{$\begin{array}{l}\text { ACEI/ } \\
\text { ARB } \\
(n=782)\end{array}$} & \multirow{2}{*}{$\begin{array}{l}\text { Non- } \\
\text { ACEI/ } \\
\text { ARB } \\
(n=262)\end{array}$} & \multicolumn{2}{|l|}{ Unadjusted } & \multicolumn{2}{|c|}{ Age, sex-adjusted } & \multicolumn{2}{|c|}{ Multivariable adjusted } \\
\hline & & & & OR $(95 \% \mathrm{Cl})$ & $P$-value & OR (95 \% Cl) & $P$-value & OR (95\% Cl) & $P$-value \\
\hline Hospitalization & $540(51.7)$ & $389(49.7)$ & $151(57.6)$ & $1.05(0.83-1.33)$ & 0.691 & $1.13(0.89-1.45)$ & 0.320 & $1.16(0.90-1.49)$ & 0.263 \\
\hline $\begin{array}{l}\text { Oxygen } \\
\text { requirement }\end{array}$ & $142(13.6)$ & $97(12.4)$ & $45(17.2)$ & $0.87(0.61-1.24)$ & 0.445 & $0.96(0.67-1.37)$ & 0.802 & $0.96(0.67-1.38)$ & 0.813 \\
\hline Severe outcome & $76(7.3)$ & $49(6.3)$ & $27(10.3)$ & $0.58(0.36-0.95)$ & 0.031 & $0.66(0.40-1.09)$ & 0.104 & $0.68(0.41-1.15)$ & 0.150 \\
\hline ICU admission & $33(3.2)$ & $20(2.6)$ & $13(5.0)$ & $0.57(0.30-1.09)$ & 0.084 & $0.60(0.31-1.16)$ & 0.127 & $0.61(0.32-1.18)$ & 0.139 \\
\hline Ventilator care & $21(2.0)$ & $12(1.5)$ & $9(3.4)$ & $0.47(0.21-1.05)$ & 0.059 & $0.51(0.23-1.14)$ & 0.101 & $0.48(0.21-1.08)$ & 0.076 \\
\hline Death & $54(5.2)$ & $35(4.5)$ & $19(7.3)$ & $0.69(0.41-1.16)$ & 0.161 & $0.78(0.45-1.33)$ & 0.358 & $0.75(0.43-1.30)$ & 0.302 \\
\hline
\end{tabular}

Data are presented as number (\%) unless otherwise specified

RAAS renin-angiotensin-aldosterone-system, $A C E I$ angiotensin-converting enzyme inhibitors, $A R B$ angiotensin receptor blockers, ICU intensive care unit, $O R$ odds ratios, $\mathrm{Cl}$ confidence intervals

COVID-19-related adverse outcomes and history of antihypertensive medication usage. Second, while information on ethnicity was absent, it is likely that most of the patients were ethnic Korean. The narrow ethnic representativeness is another limitation. Third, ARB outnumbered ACEI in the study cohort reflecting the practice pattern in East Asia. High prevalence of adverse events such as dry cough has been reported with the use of ACEI in the region [26]. Lastly, claims data usually have lag time until registration. It is possible that recent information on medical usage may be incomplete yet.

\section{Conclusions}

This study showed hypertension is associated with poor clinical outcomes in patients with COVID-19. However, the use of RAAS-blocking agents, including ACEI and $A R B$, was not associated with increased risk of any adverse study outcomes. The present study supports the current guidance to continue ACEI or ARB during the COVID-19 pandemic.

\section{Abbreviations}

ACE: Angiotensin-converting enzyme; ACEl: Angiotensin-converting enzyme inhibitors; ARB: Angiotensin receptor blockers; Cl: Confidence interval; COVID19: Coronavirus disease 2019; ICU: Intensive care unit; OR: Odds ratio; RAAS: Renin-angiotensin-aldosterone-system; S: Spike

\section{Acknowledgements}

We would like to thank Michael V. McConnel for the critical review and valuable feedback.

\section{Authors' contributions}

SHK, DHL conceived the study, KDH, JHJ, and SHP performed statistical analysis. SHK and DHL wrote the manuscript. AMD, HGW, CHW, TJY, IHC, and CHK. provided critical review. All authors reviewed and approved the manuscript.

\section{Funding}

This work was supported by the Basic Science Research Program through the National Research Foundation of Korea (grant number 2019R1C1C1006611).
Availability of data and materials

Not applicable.

\section{Declarations}

Ethics approval and consent to participate

This study was exempt from review by the Seoul National University Bundang Hospital Institutional Review Board (IRB No: X-2005-611-902). It complied with the requirements of the 2013 Declaration of Helsinki, and the need for informed consent was waived.

\section{Consent for publication}

Not applicable. No individual data in any form is disclosed.

\section{Competing interests}

SHK is a visiting scholar at Google. AMD and HGW are employees of Google Health. All other authors declare that they have no competing interests.

\section{Author details}

${ }^{1}$ Cardiovascular Center, Department of Internal Medicine, Seoul National University Bundang Hospital, Seongnam, Republic of Korea. ${ }^{2}$ Department of Internal Medicine, Seoul National University College of Medicine, Seoul, Republic of Korea. ${ }^{3}$ Google, CA, Mountain View, USA. ${ }^{4}$ Department of Statistics and Actuarial Science, Soongsil University, Seoul, Republic of Korea. ${ }^{5}$ Department of Biostatistics, College of Medicine, The Catholic University of Korea, Seoul, Republic of Korea.

Received: 11 January 2021 Accepted: 3 May 2021

Published online: 01 June 2021

\section{References}

1. Zhu N, Zhang D, Wang W, Li X, Yang B, Song J, et al. A novel coronavirus from patients with pneumonia in China, 2019. N Engl J Med. 2020;382:727-33.

2. Guan WJ, Ni ZY, Hu Y, Liang WH, Ou CQ, He JX, et al. Clinical characteristics of coronavirus disease 2019 in China. N Engl J Med. 2020;382:1708-20.

3. Wrapp D, Wang N, Corbett KS, Goldsmith JA, Hsieh CL, Abiona O, et al. Cryo-EM structure of the 2019-nCoV spike in the prefusion conformation. Science. 2020;367:1260-3.

4. Wan Y, Shang J, Graham R, Baric RS, Li F. Receptor recognition by the novel coronavirus from Wuhan: an analysis based on decade-long structural studies of SARS coronavirus. J Virol. 2020:9:e00127-20.

5. Walls AC, Park YJ, Tortorici MA, Wall A, McGuire AT, Veesler D. Structure, function, and antigenicity of the SARS-CoV-2 spike glycoprotein. Cell. 2020; 181:281-92.e6.

6. Ferrario CM, Jessup J, Chappell MC, Averill DB, Brosnihan KB, Tallant EA, et al. Effect of angiotensin-converting enzyme inhibition and angiotensin II receptor blockers on cardiac angiotensin-converting enzyme 2. Circulation. 2005;111:2605-10. 
7. Ishiyama Y, Gallagher PE, Averill DB, Tallant EA, Brosnihan KB, Ferrario CM Upregulation of angiotensin-converting enzyme 2 after myocardial infarction by blockade of angiotensin II receptors. Hypertension. 2004;43:970-6.

8. European Society of Cardiology. Position Statement of the ESC Council on Hypertension on ACE-Inhibitors and Angiotensin Receptor Blockers. https:// www.escardio.org/Councils/Council-on-Hypertension-(CHT)/News/positionstatement-of-the-esc-council-on-hypertension-on-ace-inhibitors-and-ang. Accessed date: May 2020.

9. American College of Cardiology. HFSA/ACC/AHA Statement addresses concerns re: using RAAS antagonists in COVID-19. https://www.acc.org/latestin-cardiology/articles/2020/03/17/08/59/hfsa-acc-aha-statement-addressesconcerns-re-using-raas-antagonists-in-covid-19. Accessed date: May 2020.

10. Whelton PK, Carey RM, Aronow WS, Casey DE Jr, Collins KJ, Dennison Himmelfarb C, et al 2017 ACC/AHA/AAPA/ABC/ACPM/AGS/APhA/ASH/ ASPC/NMA/PCNA guideline for the prevention, detection, evaluation, and management of high blood pressure in adults: a report of the American College of Cardiology/American Heart Association Task Force on Clinical Practice Guidelines. J Am Coll Cardiol. 2018;71:e127-248.

11. McCormack T, Boffa RJ, Jones NR, Carville S, McManus RJ. The 2018 ESC/ESH hypertension guideline and the 2019 NICE hypertension guideline, how and why they differ. Eur Heart J. 2019;40:3456-8.

12. Lee HY, Shin J, Kim GH, Park S, Ihm SH, Kim HC, et al. 2018 Korean Society of Hypertension Guidelines for the management of hypertension: part IIdiagnosis and treatment of hypertension. Clin Hypertens. 2019;25:20.

13. Vaduganathan M, Vardeny O, Michel T, McMurray JJV, Pfeffer MA, Solomon SD. Renin-angiotensin-aldosterone system inhibitors in patients with Covid19. N Engl J Med. 2020;382:1653-9.

14. Mancia G, Rea F, Ludergnani M, Apolone G, Corrao G. Renin-angiotensinaldosterone system blockers and the risk of Covid-19. N Engl J Med. 2020; 382:2431-40.

15. \#opendata4covid19. https://www.ohdsi.org/wp-content/uploads/2020/12/ Chan-PPT.pdf. Accessed Apr 16, 2020.

16. Kang SH, Kim SH, Cho JH, Yoon CH, Hwang SS, Lee HY, et al. Prevalence, awareness, treatment, and control of hypertension in Korea. Sci Rep. 2019;9: 10970.

17. Jeong SW, Kim SH, Kang SH, Kim HJ, Yoon CH, Youn TJ, et al. Mortality reduction with physical activity in patients with and without cardiovascular disease. Eur Heart J. 2019;40:3547-55.

18. Li J, Wang X, Chen J, Zhang H, Deng A. Association of renin-angiotensin system inhibitors with severity or risk of death in patients with hypertension hospitalized for coronavirus disease 2019 (COVID-19) infection in Wuhan, China. JAMA Cardiol. 2020;5:825-30

19. Zhang P, Zhu L, Cai J, Lei F, Qin JJ, Xie J, et al. Association of inpatient use of angiotensin-converting enzyme inhibitors and angiotensin II receptor blockers with mortality among patients with hypertension hospitalized with COVID-19. Circ Res. 2020;126:1671-81.

20. Palazzuoli A, Mancone M, De Ferrari GM, Forleo G, Secco GG, Ruocco GM, et al. Antecedent administration of angiotensin-converting enzyme inhibitors or angiotensin II receptor antagonists and survival after hospitalization for COVID-19 syndrome. J Am Heart Assoc. 2020;9:e017364.

21. Zhou F, Yu T, Du R, Fan G, Liu Y, Liu Z, et al. Clinical course and risk factors for mortality of adult inpatients with COVID-19 in Wuhan, China: a retrospective cohort study. Lancet. 2020;395:1054-62.

22. Korean Society Hypertension (KSH), Hypertension Epidemiology Research Working Group. Kim HC, Cho MC. Korea hypertension fact sheet 2018. Clin Hypertens. 2018;24:13.

23. An J, Wei R, Zhou H, Luong TQ, Gould MK, Mefford MT, et al. Angiotensinconverting enzyme inhibitors or angiotensin receptor blockers use and COVID-19 infection among 824650 patients with hypertension from a US integrated healthcare system. J Am Heart Assoc. 2021;10:e019669.

24. Morales DR, Conover MM, You SC, Pratt N, Kostka K, Duarte-Salles T, et al. Reninangiotensin system blockers and susceptibility to COVID-19: an international, open science, cohort analysis. Lancet Digit Health. 2021;3:e98-114.

25. Zastrow M. South Korea is reporting intimate details of COVID-19 cases: has it helped? Nature. 2020. https://doi.org/10.1038/d41586-020-00740-y.

26. Woo KS, Nicholls MG. High prevalence of persistent cough with angiotensin converting enzyme inhibitors in Chinese. Br J Clin Pharmacol. 1995;40:141-4.

\section{Publisher's Note}

Springer Nature remains neutral with regard to jurisdictional claims in published maps and institutional affiliations.

\section{Ready to submit your research? Choose BMC and benefit from}

- fast, convenient online submission

- thorough peer review by experienced researchers in your field

- rapid publication on acceptance

- support for research data, including large and complex data types

- gold Open Access which fosters wider collaboration and increased citations

- maximum visibility for your research: over $100 \mathrm{M}$ website views per year

At BMC, research is always in progress.

Learn more biomedcentral.com/submissions 